\title{
The Effects of Elementary Students' Science Learning in CLIL
}

\author{
Yi-Ching Huang ${ }^{1}$ \\ ${ }^{1}$ Department of Applied Foreign Languages, Central Taiwan University of Science and Technology, Taichung, \\ Taiwan \\ Correspondence: Yi-Ching Huang, Department of Applied Foreign Languages, Central Taiwan University of \\ Science and Technology, Taichung, Taiwan.
}

Received: December 19, 2019

Accepted: January 6, 2020

Online Published: January 8, 2020

doi: 10.5539/elt.v13n2p1

URL: https://doi.org/10.5539/elt.v13n2p1

\begin{abstract}
The purpose of this study was to explore the effects of students' science learning in Content and Language Integrated Learning (CLIL) at one elementary school in Taiwan. This study investigated student perceptions of both the content and language achievement of science learning in CLIL. Data collection techniques included graphic organizers, individual interviews, students' self-assessment, and students' tests. Findings showed that CLIL helped enrich student vocabulary size, foster student science knowledge, and lead them to expect to learn other subjects in English. They also enjoyed the CLIL approach, but expressed limited knowledge about the school flower.
\end{abstract}

Keywords: Content and Language Integrated Learning (CLIL), science education, student perception, learning effects

\section{Introduction}

\subsection{Introduce the Problem}

Content and Language Integrated Learning (CLIL) programs were widespread in primary and secondary education across Europe. The term "CLIL" covers a wide range of educational practices in which a Foreign Language (FL), mainly English, is used to teach content subject matter, enabling content and language to be learned (Dalton-Puffer, 2011; Coyle, 2013; Turner, 2013). The main feature of the CLIL methodology is that CLIL students "learn to use language and use language to learn" (Mehisto, Marsh \& Frigols, 2008, p. 26) leading to language and communication, since integrated learning entails a twin focus on meaning and form. CLIL classroom activities should be focused on both the acquisition of disciplinary competence and communicative competence, in terms of both reception and production. Students are given opportunities to address concrete issues of the real world in a language that is not their native language. They learn that things happen in worlds different from their own, identify relationships between concepts, and identify the principles that support them (Quartpelle \& Schameitat, 2012).

\subsection{Language Learning in CLIL}

The implementation of CLIL has been the focus of research since its introduction, with results suggesting broadly positive outcomes. Several studies argue that CLIL developed student content learning and cognition through a foreign language (Niteo Moreno de Diexmas, 2016; Tedick \& Wesley, 2015; Castellano Rico 2015; Dalton-Puffer, 2008; Llinares, 2017; Llinares \& Dalton-Puffer, 2015). Niteo Moreno de Diexmas (2016) found young learners aged 9-10 improved their language competence and language skills via CLIL. Results showed that spoken production and interaction were positively affected for the first language competence, although CLIL learners showed higher scores in reading and writing. Interestingly, the differences were not significant. The most passive affected language competence was listening, in which CLIL students scored lower than their counterparts, but to no significant extent. The aspects most benefited by CLIL methodology were those of oral production and oral interaction. The CLIL group significantly outperformed the non-CLIL group in their use of oral vocabulary, answering questions, fluency, rhythm, pronunciation and intonation, active listening, respect for the rules of communicative exchange and preparing conversations. However, CLIL students wrote compositions with more grammatical mistakes and less clear presentation, and presented problems in understanding vocabulary in oral texts, and the discrepancies were significant. Tedick \& Wesley (2015) stated that students in CLIL programs acquired high levels of proficiency in reading and listening but often have problems in 
grammatical accuracy when writing and speaking. In addition, Castellano Rico (2015) found that CLIL learners used significantly more cognitive strategies in learning vocabulary than EFL learners, and had a larger receptive vocabulary.

Dalton-Puffer (2008) concluded that CLIL learners' linguistic performance was satisfactory in certain areas such as listening and reading skills, vocabulary, morphology, creativity, fluency, risk-taking and quantity. However, some competences such as syntax, writing, informal language and pronunciation remained unaffected.

Llinares (2017) contended that the implementation of CLIL in different subjects and different tasks can help students to learn content and second language learning in different ways. Llinares and Dalton-Puffer (2015) suggested that a teacher focus on meaningful and collaborative interaction in CLIL classroom enhanced students' higher-order thinking skills. Pladevall-Ballester (2017) identified four ways to enhance CLIL learning: making learners more familiar with the foreign language, providing increased exposure which needs to be accompanied by scaffolding output opportunities, enhancing their foreign language motivation, and reinforcing their cognitive engagement.

\subsection{Students' Perceptions of CLIL}

Several researchers have investigated student perceptions of their CLIL learning to understand more about student learning. Studies focusing on positive outcomes such as motivation, active attitudes towards language learning, satisfaction and increased confidence have presented positive results for CLIL. CLIL learners tended to be more motivated to learn the foreign language than their non-CLIL counterparts and had more positive attitudes towards language learning (Doiz, Lasagabaster and Sierra 2014; Pérez-Cañado 2012). They also developed better communication skills and linguistic confidence when they succeeded in mastering the content subjects in the foreign language (Dale and Tanner 2012).

Hunt (2011) examined learners' perceptions of their CLIL learning experience, their enjoyment, evaluation of their activities, and their motivation. The study also reported that the majority of learners enjoyed the lessons and activities in CLIL settings, clearly understood the learning objectives, and were confident about their progress in their learning. Li and Ruan (2015) indicated that learners' beliefs underwent significant changes after CLIL practices, including changes in assessment, teachers' roles, the relationship between subjects and the target language, and the learners' involvement in extracurricular activities.

In Taiwan, a number of studies (Chang, 2010; Hsieh \& Kang, 2007; Wu, 2006) have reported that students enrolled in CLIL courses showed a more positive learning attitude and perceived an increase in their English proficiency, particularly in their listening skills. Nevertheless, these studies noted that students' lower English proficiency can hinder the comprehension of content courses and puts pressure on them when expressing themselves freely in CLIL classes. Yeh (2008) found no significant differences in reading comprehension ability or learning attitudes towards English among CLIL and non-CLIL groups in an elementary school. The non-CLIL group performed significantly better than the CLIL group in listening, vocabulary, and sentence recognition.

Based on the foregoing discussion, little research has been done on the CLIL areas related to students' perceptions affected by CLIL, and learners' actual progression in both content and language achievement. The selected elementary school in this study featured dancing doll orchids as a symbol of the school. The curriculum in many classes was designed based on the dancing doll orchids in this school. If students in the selected school can learn about plants in science learning in CLIL settings, they may come to understand more about globalization and localization. This can lead to "glocalization", defined by Kraidy (2001) as "the ability of a culture, when it encounters other strong cultures, to absorb influences that naturally fit into and can enrich culture, to resist to those things that are truly alien”. By using a foreign language, students can learn to see local culture through global eyes. Therefore, the purpose of this study was to explore the effects of students' science learning using CLIL at one elementary school in Taiwan. This study thus investigated the perception of CLIL students' science learning and their progress in both content and language achievement, in order to identify the effects of CLIL.

\section{Method}

Perez-Canado (2012) indicated that the research design and methodology on CLIL should employ mixed methods, adopt triangulation, and employ multivariate procedures. The combination of quantitative and qualitative methods provides the researcher with different perspectives that nurture the analysis and make it more valid. Thus, this study adopted used both quantitative and qualitative methods to interpret and analyze the results of the study. 


\subsection{Research Context and Participants}

This research involved 30 students between 10-12 years old from an elementary school located in Taichung, Taiwan. The students had only a basic level of English. This elementary school did not have CLIL program implemented in any courses. Students took one science course once a week, 3 hours per class in this study. The program lasted for one semester. The class was taught by a South African teacher who has been teaching science at a bilingual elementary school in Taiwan for over 5 years. This science teacher needed to discuss the class objectives and curriculum design with the local teacher who teaches science at the elementary school. Additionally, to reduce student stress from English learning with a native speaker of English, 6 Taiwanese college students who were majoring in English assisted the students in the classroom. When the elementary school students had difficulty understanding, the college students assisted the elementary students in Chinese and English.

\subsection{Data Collection Techniques}

This study employed the following data collection techniques: graphic organizers, interviews, students' self-assessment, and students' tests. The range of data collection tools addresses the issues of validity, "the degree to which scientific observations actually measure or record what they purport to measure" (Pelto \& Pelto, cited by Mills, 1999, p. 84) and reliability, the precision of the data. Triangulation is "best known way of checking for validity" (Burns, 2010, p.163). A triangulation matrix was used to ensure corroboration of findings as different independent pieces of information point in the same direction.

\subsubsection{Graphic organizers}

According to Lankshear et al. (2004), graphic organizers represent specific evidence of what the participants carry out within their context. The graphic organizes merged both the language and the content by explicitly giving the students the key vocabulary of the text and asking them questions to challenge their thinking and conceptual development. These graphic organizers (Figure 1) were used to help students and the teacher evaluate their comprehension of science learning.

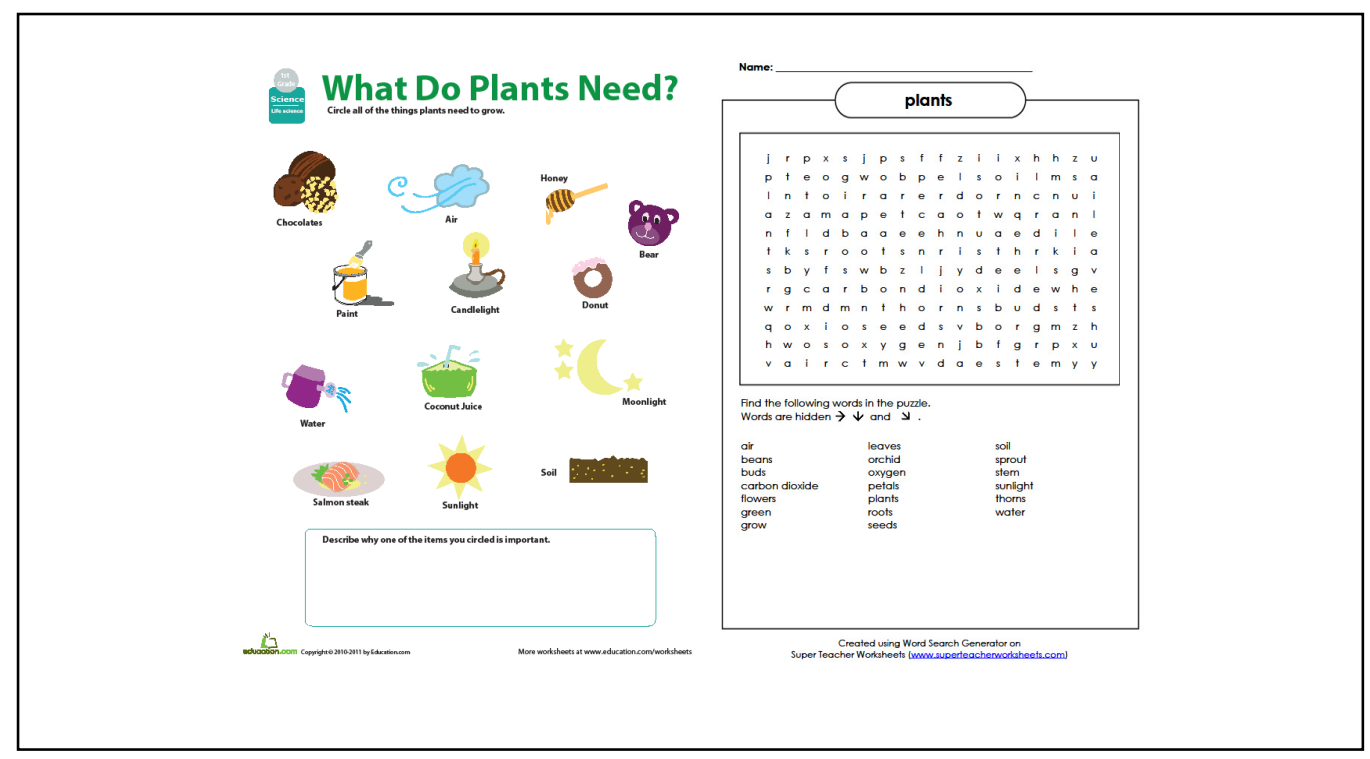

Figure 1. Sample of students' graphic organizer

\subsubsection{Interviews}

Semi-structured interviews were conducted to gather student perceptions of the project, concepts, and scientific knowledge they learned, and their recommendations. The semi-structured interview provided a bigger picture of self-regulation and helped clarify the complex connections of events and processes in addressing a context-specific issue (Rose, 2012, Woodrow, 2005). The interview protocol was designed based on the questionnaire results, to give students the opportunity to elaborate on their questionnaire answers. The interviewees consisted of 22 elementary students and one South African teacher. Each interview lasted one hour. The entire interview was tape-recorded. Chinese was used to interview the students, but the data was then translated into English by the researcher. 


\subsubsection{Students' self-assessment}

Maggie (2012) argued that using self-assessment helped to make learners more independent via monitoring their own progress. This study adapted the self-assessment questionnaire of Maggie (2012) to understand students' learning achievements in the CLIL program. The self-assessment questionnaire, consisting of 10 four-Likert scale items, aimed to elicit CLIL learners' perceptions of their language and content achievements and the relationship between the two after studying in the CLIL program. The self-assessment questionnaire used in this study consisted of two aspects: language (Table 1) and content (Table 2). Descriptive analysis was used to examine whether participants' perceptions exhibited significant differences.

Table 1. The self-assessment questionnaire (language)

$\begin{aligned} & \text { when I speak in a foreign } \\ & \text { language I consider important }\end{aligned}$
$\begin{aligned} & \text { a. the correct pronunciation of } \\ & \text { words }\end{aligned}$
b. the ability to improvise
c. knowledge of vocabulary
d. knowledge of the contents
e. the use of facial expressions,
gestures and body movements
f. grammatical correctness
g. clarity of exposition
h. the ability to reformulate
i. check that the others
understand me when I speak
j. others:

Table 2. The self-assessment questionnaire (content)

\begin{tabular}{lcccc}
\hline $\begin{array}{l}\text { When I learn dancing doll orchid, I } \\
\text { can... }\end{array}$ & $\begin{array}{c}\text { Very } \\
\text { agree }\end{array}$ & Agree & Was not sure & $\begin{array}{c}\text { Did not } \\
\text { agree }\end{array}$ \\
\hline
\end{tabular}

1. I can clearly say the structure of the
plant

2. I can clearly know the nutritious source of what dancing doll orchid needs

3. I know the varied colors of dancing doll orchid

4. I can clearly know the plant's process of growing

5. I can simply introduce dancing doll orchid

6. I can say the characteristics of dancing doll orchid

7. I can use my knowledge about plants in the class

8. I know more about dancing doll orchid after the CLIL class

\subsubsection{Students' tests}

Students were required to take pre and post tests (Figure 2) of science knowledge. The tests were used to measure student progress in quantitative methods. The science teacher designed the test, which was related to plant requirements, plant parts, the life stages of plants, and plant cells. The test required approximately 30 
minutes.

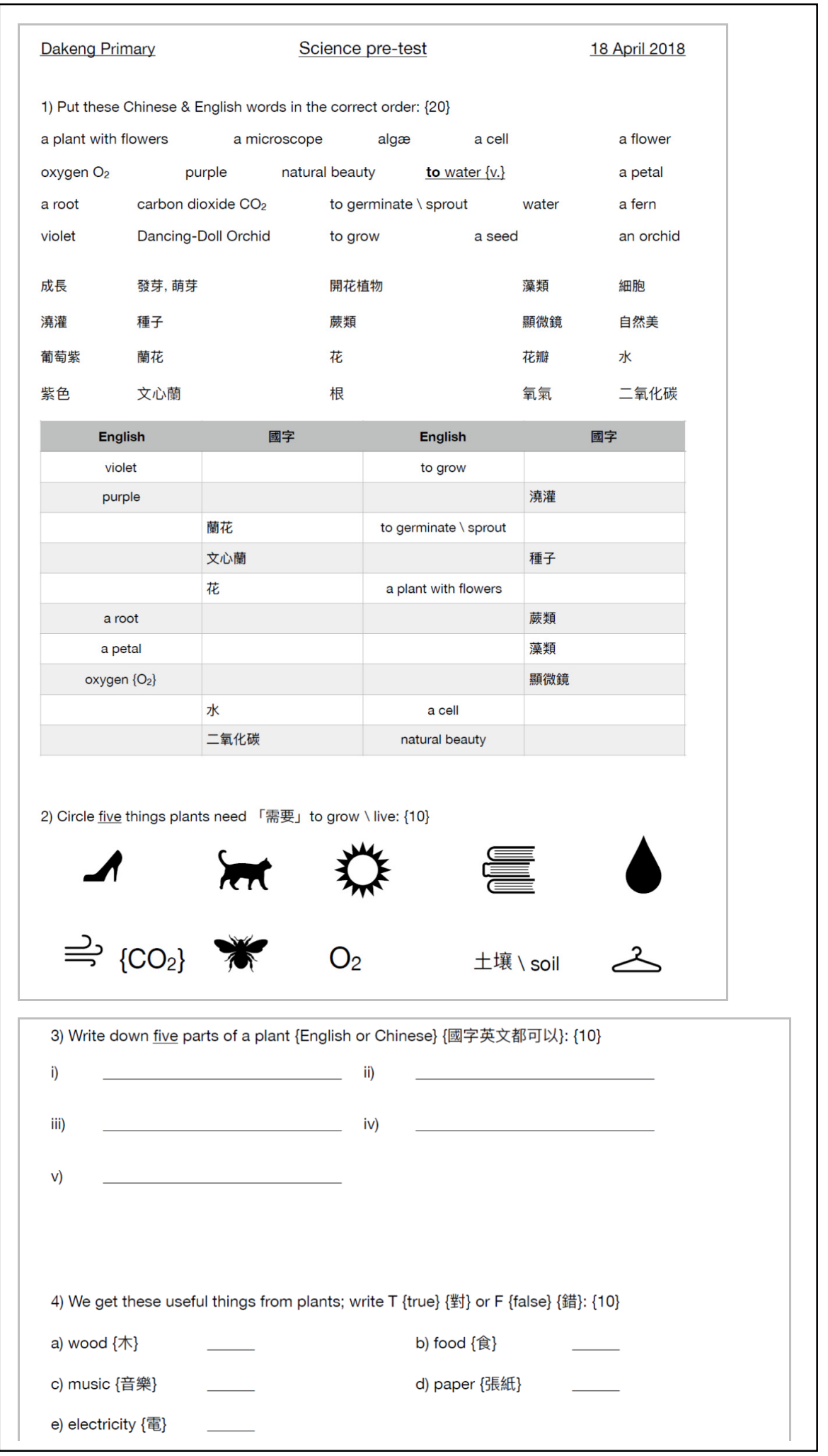

Figure 2. Sample items from student test

\subsection{Data Analysis}

Data collection techniques in this study included graphic organizers, interviews, students' self-assessment, and students' tests. This study employed a mix methods design combining quantitative and qualitative methods. 


\subsubsection{Quantitative Analysis}

A statistical analysis of the data was performed with the aid of the SPSS program in its 21.0 version. Participants' scores on the pre- and post-tests were compared via t tests to determine whether the participants had made any significant progress after studying in the CLIL program.

\subsubsection{Qualitative Analysis}

The main tools for analyzing and synthesizing qualitative data involve categorizing (Burns, 2010), which implies sorting objects into logical groups and developing a well-structured theoretical framework that explains the phenomena under investigation. In this study both quantitative and qualitative analysis were interwoven in order to identify CLIL learning outcomes that can be grouped as categories, which later can be used to interpret their progress in both content and language achievement.

\section{Results}

In the Results section, summarize the collected data and the analysis performed on those data relevant to the discourse that is to follow. Report the data in sufficient detail to justify your conclusions. Mention all relevant results, including those that run counter to expectation; be sure to include small effect sizes (or statistically nonsignificant findings) when theory predicts large (or statistically significant) ones. Do not hide uncomfortable results by omission. Do not include individual scores or raw data with the exception, for example, of single-case designs or illustrative examples. In the spirit of data sharing (encouraged by APA and other professional associations and sometimes required by funding agencies), raw data, including study characteristics and indivldual effect sizes used in a meta -analysis, can be made available on supplemental online archives.

The major findings of the study were:

1. CLIL enriched student vocabulary size

2. CLIL fostered student science knowledge

3. CLIL led them to expect to learn other subjects in English

4. Students enjoyed the CLIL approach

5. Students had only limited knowledge about the school flower

\subsection{CLIL Enriched Student Vocabulary Size}

During the interviews with the 22 students they stated that CLIL teaching helped them know the words and understand the meaning of words. Through the interviews, students were able to express vocabulary about science education. When asked what vocabulary they learned after the class, students reported some words they had memorized (Table 3).

Table 3. Words Students Reported

\begin{tabular}{cccc}
\hline Flower & Sun & Sprout & A petal \\
\hline Water & To water & To grow & Orange \\
Blue & Green & Violet & Yellow \\
Purple & Pink & Air & Soil \\
Sprouting seed & To protect & To geminate & To care for \\
To look after & To sprout & A bud & Plant with flower \\
Stem & Dancing doll orchid & Light & Oxygen \\
Carbon dioxide & A thorn & To place & \\
\hline
\end{tabular}

Through the pre-post tests, Table 4 showed that the mean score increased from 64.45 to 77.09 . This showed that students' vocabulary size increased after the CLIL teaching. 
Table 5. Result of Pre-post tests

\begin{tabular}{cccccc}
\hline \multicolumn{5}{c}{ Paired Samples Statistics } \\
\hline \multirow{2}{*}{ Pair 1 } & PRE & Mean & $N$ & Std. Deviation & Std. Error Mean \\
\cline { 2 - 5 } POST & 64.45 & 22 & 11.657 & 2.485 \\
& 77.09 & 22 & 14.017 & 2.988 \\
\hline
\end{tabular}

\begin{tabular}{|c|c|c|c|c|c|c|c|c|c|}
\hline \multicolumn{10}{|c|}{ Paired Samples Test } \\
\hline & & \multicolumn{5}{|c|}{ Paired Differences } & \multirow{3}{*}{$t$} & \multirow{3}{*}{$d f$} & \multirow{3}{*}{$\begin{array}{c}\text { Sig. } \\
\text { (2-tailed) }\end{array}$} \\
\hline & & \multirow[t]{2}{*}{ Mean } & \multirow[t]{2}{*}{$\begin{array}{c}\text { Std. } \\
\text { Deviation }\end{array}$} & \multirow[t]{2}{*}{$\begin{array}{c}\text { Std. Error } \\
\text { Mean }\end{array}$} & \multicolumn{2}{|c|}{$\begin{array}{c}\text { 95\% Confidence } \\
\text { Interval }\end{array}$} & & & \\
\hline & & & & & Lower & Upper & & & \\
\hline $\begin{array}{c}\text { Pair } \\
1\end{array}$ & $\begin{array}{l}\text { PRE - } \\
\text { POST }\end{array}$ & -12.636 & 12.927 & 2.756 & -18.368 & -6.905 & -4.585 & 21 & .000 \\
\hline
\end{tabular}

$<0.001$

Based on the graphic organizers, Figure 3 shows that the students knew how to use, identify, and spell the words about plants. Clearly, students learned words more about science. However, although the evidence shows that the students learned vocabulary words, the vocabulary learning can be viewed as receptive learning rather than productive learning. How schoolchildren learn the productive learning through CLIL instruction should be explored in future research.

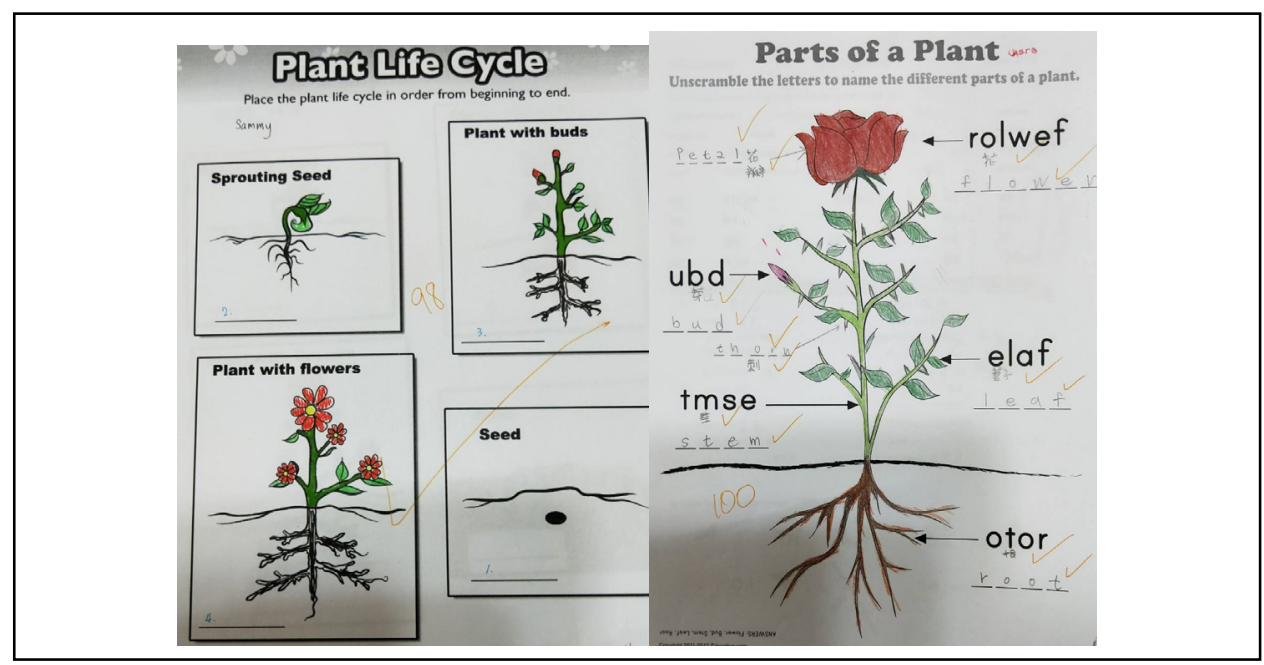

Figure 3. Sample of students' graphic organizer

From the self-assessment questionnaire of language, forty-one percent of students agreed with the statement "when I speak in a foreign language, I consider the correct pronunciation of words", 14\% strongly agreed, $37 \%$ were not sure, and $9 \%$ did not agree. Students apparently did not feel that correct pronunciation of words was important in speaking a foreign language.

\subsection{CLIL Fostered Student Science Knowledge}

When asked if they learned science knowledge through the CLIL approach, 18 students in the interviews reported that they learned how to plant, plant structure, watering, growth needs for plants, the process of growth, and the process of planting beans in the CLIL classroom. The followings were student' responses when asked about their learning about science.

Student 4: Yes, the structure of plants, and categories.

Student 6: I learned the names of petals of plants.

Student 1: I learned how bean sprouts grow and the process of plant growth.

Through interviews in this study, 16 students indicated that they liked the theme of dancing doll orchids in the 
CLIL classroom when asked about the dancing doll orchids. Responses included:

Student 2: I liked it. The class was fun.

Student 4: I liked the class, because we can play games, and read English words.

Student 6: This was an interesting teaching approach.

Student 7: I liked it because I learned some knowledge about Dancing-doll orchids.

Student 13: I learned to see dancing doll orchids in different ways.

Student 15: I know more about dancing doll orchids now. So, I can tell foreigners about our flower.

Student 16: Dancing doll orchids are species of flowers, and also have more varieties.

Student 17: Dancing doll orchids are a type of orchids ....just like a person with a skirt...but I don't know why it is yellow.

Student 20: I know more about dancing doll orchids.

$41 \%$ of the students strongly agreed with the statement "I can clearly know the source of the nutrition dancing doll orchids need" in the "content" self-assessment questionnaire, $18 \%$ agreed, $27 \%$ were not sure, and $14 \%$ did not agree. $46 \%$ of the students Strongly agreed or agreed with the statement in the "content" questionnaire "I know the varied colors of the dancing doll orchid", $14 \%$ agreed, and $41 \%$ were not sure. $41 \%$ of the students agreed with the statement "I can learn the knowledge of the contents" in the "language" questionnaire, $23 \%$ strongly agreed, $23 \%$ were not sure, and $14 \%$ did not agree. These findings showed that students thought they learned content knowledge through CLIL.

Figures 4 and 5 show that students learned science knowledge and vocabulary in both Chinese and English. When students did not know how to write the answer in English, they were allowed to write their responses in Chinese. This met the learning goal of CLIL that L1 and L2 can be used simultaneously in class based on students' understanding of the content.

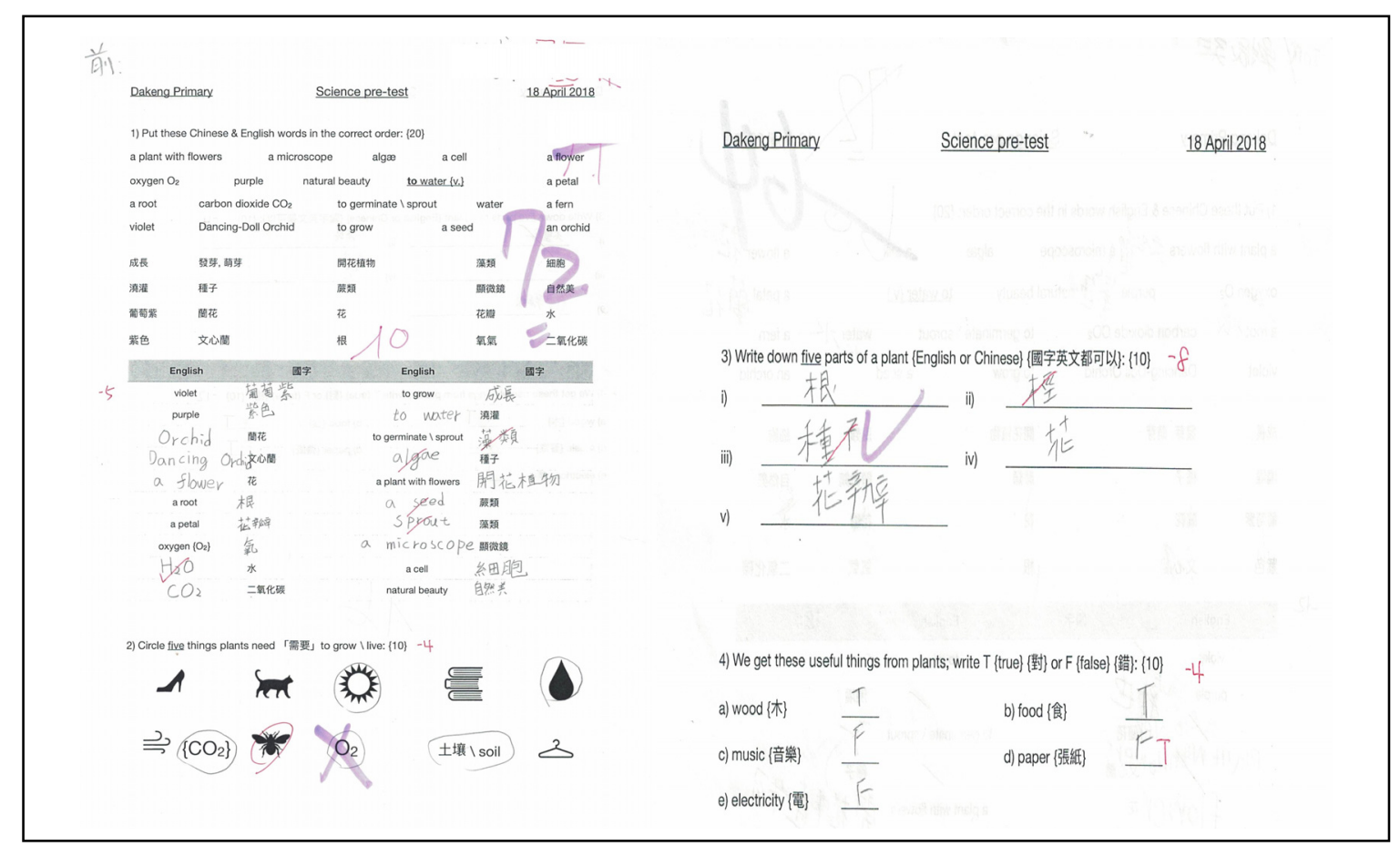

Figure 4. Sample of students' response in Science tests 


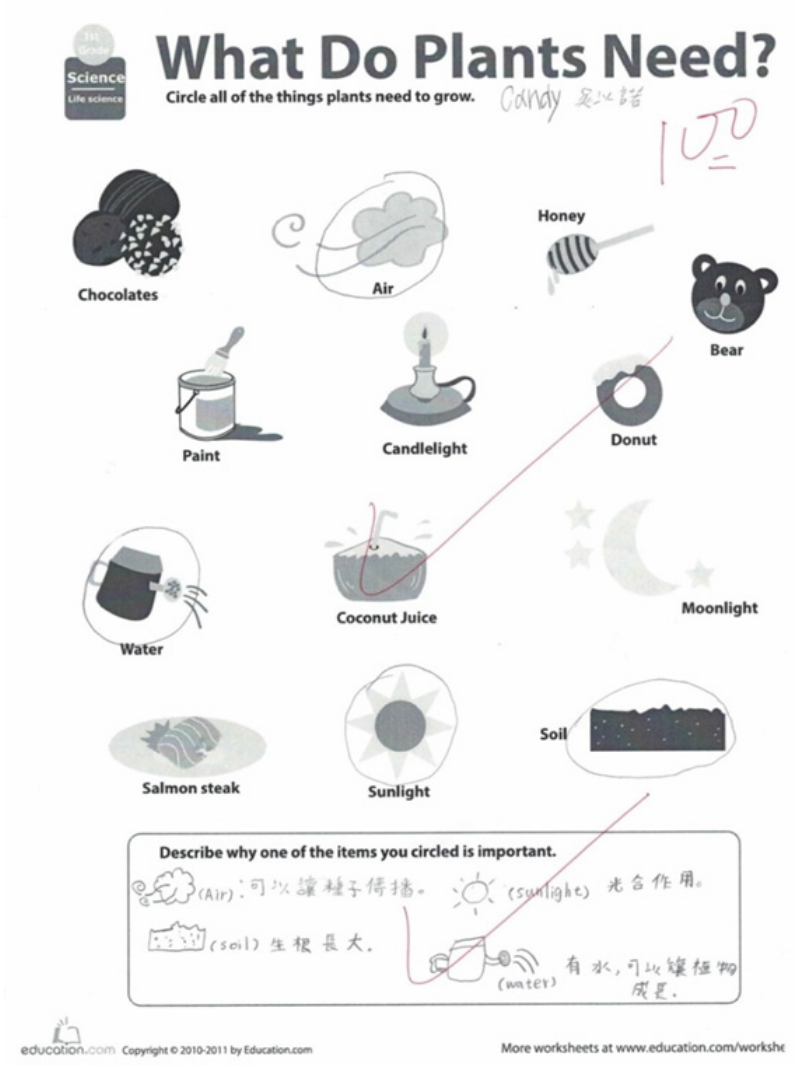

Figure 5. Sample of students' response in science tests 3.3 CLIL Led Them to Expect to Learn other Subjects in English

Although this study focused on learning science in English, 13 students reported that they would like to learn other subjects in English. Student responses include:

Student 12: I would like to learn math in English, because I think math is fun.

Student 5: ....they can learn more knowledge in English

Student 9: English class is fun so learning something in English would be fun.

Student 10: I would like to learn something about communication, because English communication is helpful in more topics than just learning plants.

Student 1: learning other subjects in English would be more fun

The response from students in this study met the core reason for the wide use of CLIL since the 1990s (Marsh, 2002). Marsh (2002) indicated that CLIL aimed to put both language and non-language content on a type of continuum without focusing on a preference for one or the other. CLIL in Europe prepares students to become internationalized, global and multilingual people for living in a society. The purpose also emphasized respect for other nationalities by learning other languages and culture.

\subsection{Students Enjoyed the CLIL Approach}

Through interviews, 16 students reported that they enjoyed learning science in English in this study. When asking students' perceptions about learning science in English, their responses showed as follows:

Student 1: I thought this was fun, because science is fun.

Student 2: It is fun. And we can know more about plants.

Student 3: We can learn the usage of science in English.

Student 21: It is rare to learn science in English and Chinese, so progress would be made if they learn the contents in English.

Student 20: The CLIL approach was interesting. 


\subsection{Students had OnlyLimited Knowledge about the School Flower}

Dancing doll orchids are the theme and focus of the curriculum design at the selected elementary school. Many teaching activities are connected with dancing doll orchids. When asking students about their perceptions of dancing doll orchids in school, 8 students in the interviews said dancing doll orchids are featured at the school.

Dancing doll orchids are the theme and focus of the curriculum design at the selected elementary school. Many teaching activities are connected with dancing doll orchids. When asking students about their perceptions of dancing doll orchids in school, 8 students in the interviews said dancing doll orchids are featured at the school.

The evidence from the interviews showed that students in this school appeared to have no clear perception of the dancing doll orchids as their school feature. Although students have ambiguous ideas about the school flower, "glocalization" still can be the goal of the school using dancing doll orchids as the school flower.

\section{Discussion}

This study explores the effects of students' science learning in CLIL and student perceptions of science learning through English in Taiwan. The results of this study showed that the CLIL approach can enrich students' vocabulary size, and foster students' science knowledge. Students reported that they looked forward to learning other subjects in English through the CLIL approach, and enjoyed the integrated learning between language and content. Although dancing doll orchids were their school flower, students showed that they had limited knowledge about the plant. The positive learning outcomes for vocabulary size in this study were consistent with the findings of other researchers that vocabulary acquisition is significant in CLIL learning (Feixas, Codo, Couso, Espinet, Masats, 2009; Marques, 2007; Catalan \& de Zaribe, 2009).

According to the evidence of this study, students perceived the CLIL approach as an interesting and acceptable learning approach. This finding corresponded to the argument of Coyle (2007) that cognitive engagement of the learners' developmental level ended up effective learning because teaching content through language increases the cognitive challenge and promotes higher order thinking skills. Students in this study said that the CLIL teaching was fun and interesting, and the teacher's instruction focused on games which were fun for their language learning and science learning. Given the fact that students enjoyed the CLIL approach in this study, this study shows that students had shown a preference for activities in CLIL which required higher interaction and involvement for their learning. The games rather than textbooks would be an obvious preference for maintaining student interest. In addition, this implies that the teacher and students did not expect focusing on grammatical fine-tuning in the classroom.

The result of the study also showed that students expected to learn other subjects in English. This is consistent with Huttner, Dalton-Puffer, and Smit (2013) that students' beliefs about the language learning can affect how learners make sense of their experiences, organize their learning, and shape their motivation. Furthermore, given that students looked forward to learning other subjects in English, it appears that students enjoyed the CLIL approach. Student cognitive gains in this study show the positive effect associated with the implementation of CLIL (Lorenzo et al., 2010).

The findings of this study demonstrate that students gained knowledge about science education, and words about science. Students mentioned that if they learned more science knowledge, and improved their English proficiency through CLIL, they can introduce their culture to foreigners, and make friends with foreigners. This indicates that elementary students in this study expected to broaden their global perspectives. This is consistent with Coyle (2013) who argued that students' self-perceptions of their learning outcomes, students' perceived value of their learning progress, and the force students desire to learn were the key elements for successful learning. Students report that they improved their language learning imply that student self-confidence increased in the CLIL classroom. The results of this study are similar to those of Dalton-Puffer (2009), who found that student perception of CLIL benefits included increased self-confidence and decreased fear of speaking a foreign language.

In sum, the participants and the science teacher at the selected school showed acceptance of CLIL in this study. Though the effects of CLIL in this study did not present comprehensive learning results regarding both language and content, students reported significant and positive effects on their learning in CLIL. This study also explored student perceptions of their science learning through English, and showed their expectations for CLIL learning in the future.

\section{Conclusion}

The purpose of this study was to explore the effects of students' science learning using CLIL at one elementary school in Taiwan. Specifically, this study intended to investigate the perceptions of students towards science 
learning and their progress in both content and language using the CLIL approach. The major findings of the study include that CLIL enriched student vocabulary size, fostered student science knowledge, and increased their interest in learning other subjects in English. They appeared to enjoy the CLIL approach, yet exhibited limited knowledge about the school flower.

Several limitations of this study should be noted. First, interviews with teachers should be performed to obtain another perspective on students' CLIL learning. Second, more CLIL training should be offered to college students as teaching assistants in CLIL classrooms. The college students in this study were afraid to use Chinese to help the elementary students when they had difficulties understanding what the science teacher said. These college students could not have a concrete ideas about the proportion of English to Chinese in the CLIL classroom. If college students as teaching assistants clearly understand the differences between Hard CLIL and Soft CLIL (Bently, 2010), they can aid collaboration with the content teacher who is a native-speaker of English.

\section{References}

Barbero T. \& Maggi F. (2011). Assessment and Evaluation in CLIL. In D. Marsh, O. Meyer. Quality Interfaces. EAP, Eichstaett Academic Press UG, Eichstätt.

Bently, K. (2010). The Teaching Knowledge Course CLIL Module. Cambridge: Cambridge University Press.

Black, P. \& William, D. (2003). In praise of educational research: Formative assessment. British Educational Research Journal, 29(5), 623-637. https://doi.org/10.1080/0141192032000133721

Breidbach, S. \& Viebrock, B. (2012). In focus: CLIL in Germany: Results from recent research in a contested field of education. International CLIL Research Journal, 1(4), 5-16.

Bruton, A. (2011). Is CLIL so beneficial, or list selective? Re-evaluating some of the research. System, 39(4), 523-532. http://dx.doi.org/10.1016/j.system.2011.08.002

Bui Le Diem Trang \& Truong Thi Thanh Nga (2015). CLIL in Primary English Lessons: Teachers' Perspectives. Language Education in Asia, 6(2), 90-106. http://dx.doi.org/10.5746/LEiA/15/V6/I2/A2/Bui_Truong

Castellano Risco, I.O. (2015). How a CLIL approach may affect the size of receptive vocabulary and the use of vocabulary learning strategies: An empirical study focused on Extremaduran secondary learners. (Unpublished master's thesis). University of Extremadura, Badajoz, Spain.

Catalan, R. J \& Zarobe, Y. R. (2009). The receptive vocabulary of EFL learners in two instructional contexts: CLIL versus non-CLIL instruction. In Y. R. de Zarobe \& R. J. Catalan (Eds.), Content and language integrated learning: Evidence from research in Europe (pp. 8192). Bristol: Multilingual Matters.

Cenos, J. \& Gorter, D. (2011). Focus on multilingualism: A study of trilingual writing. The Modern Language Journal, 95, 356-369. https://doi.org/10.1111/j.1540-4781.2011.01206.x

Chang, Y. Y. (2010). English-medium instruction for subject courses in tertiary education: Reactions from Taiwanese Undergraduate students. Taiwan International ESP Journal, 2(1), 55-84.

CILT. (2008). Intensive and immersion courses. http: www.cilt.org.uk/14to19/intensive/.

Coonan, C. (2007). Insider view of the CLIL class through teacher self-observation-introspection. International Journal of Bilingual Education and Bilingualism, 10(5), 625-646. https://doi.org/10.2167/beb463.0

Coyle, D. (2007). Content and language integrated learning: Towards a connected research agenda for CLIL pedagogies. International Journal of Bilingual Education and Bilingualism, 10(5), 543-562. https://doi.org/10.2167/beb459.0

Coyle, D. (2013). Listening to learners: An investigation into successful learning across CLIL contexts. International Journal of Bilingual Education and Bilingualism, 16(3), 244-266. https://doi.org/10.1080/13670050.2013.777384

Dafouz Milne, E., Llinares, A. \& Morton, T. (2010). CLIL across contexts: A scaffolding framework for CLIL teacher education. Vienna English Working Papers, 19(3), 12-20.

Dale, L. and Tanner, R. (2012). CLIL Activities. Cambridge: Cambridge University Press.

Dalton-Puffer, C. (2007). Discourse in Content and Language Integrated Learning (CLIL) classrooms. Amsterdam, Netherlands: John Benjamins.

Dalton-Puffer, C. (2008). Outcomes and processes in Content and Language Integrated Learning (CLIL): current research from Europe. In Dalanoy, W. \& Volkman, L. (Eds.) Future Perspectives for English Language Teaching (pp139-154). Heidelberg. 
Dalton-Puffer, C. (2009). Communicative competence and the CLIL lesson. InY. Ruiz de Zarobe \& R. M. Jimenez Catalan (eds). Content and Language Integrated Learning: Evidence from Research in Europe, 197-214. Bristol: Multilingual Matters.

Dalton-Puffer, C. (2011). Content-and-Language Integrated Learning: from practice to principles? Annual Review of Applied Linguistics, 31, 182-204. https://doi.org/10.1017/S0267190511000092

Denman, J., Tanner, R. \& Grafff, R. (2013). CLIL in Junior Vocational Secondary Education: Challenges and opportunities for teaching and learning. International Journal of Bilingual Education and Bilingualism, 16 (3), 285-300. http://dx.doi.org/10.1080/13670050.2013.777386

Doiz, A; Lasagabaster, D \& Sierra, J. M. (2014). CLIL and Motivation: The Effect of Individual and Contextual Variables. Language Learning Journal, 42(2), 209-224. https://doi.org/10.1080/09571736.2014.889508

Ellison, M. (2015). CLIL: The added value to English language teacher education for young learners. LINGVRVMARENA, 6, 59-69.

Eurydice Report. (2006). Content and Language Integrated Learning (CLIL) at School in Europe. Brussels: European Commission.

Feixas, M., Codo, E., Couso, D., Espinet, M. \& Masats, D. (2009). Ensenar en ingl es en la universidad: Reflexiones del alumnado y el profesorado en torno a dos experiencias AICLE [Teaching English at the university: Student and teacher reflections on two CLIL experiences]. In R. Roig, J. Blasco, M. A. Cano, R. Gilar, A. Lledo \& C. Ma nas (Eds.), Investigar desde un contexto educativo innovador [Investigating from an innovative instruction context] (pp. 137153). Alicante: Editorial Marfil.

Garcia Esteban, S. (2015). Integrating curricular contents and language through storytelling: criteria for effective CLIL lesson planning. Social and Behavioral Sciences, 212, $47-51$. https://doi.org/10.1016/j.sbspro.2015.11.297

Garcia Mayo, M.D.P. \& Lazaro Ibarrola, A. (2015). Do children negotiate for meaning in task-based interaction? Evidence from CLIL and EFL settings. System, 54, 40-54.

Gierlinger, E. M. (2017). The challenging interplay of context, context, and community for CLIL implementations and a didactic model to cope with CLIL's Hybrid pedagogy. English as a Global Language Education (EaGLE) Journal, 3(1), 63-80. http://dx.doi.org/10.6294/EaGLE.2017.0301.04

Goris, J., Denessen, E \& Verhoeven, L. (2017). The contribution of CLIL to learners' international orientation and EFL confidence. The Language Learning Journal, http://dx.doi.org/10.1080/09571736.2016.1275034

Grosjean, F. (2008). Studying bilinguals. Oxford: Oxford University Press.

Hsieh, S. H. \& Kang, S. C. (2007). Effectiveness of English-Medium Instruction of an Engineering Course and Strategies Used by the Teacher. Accessed June 30, 2013. http://www.ctld.ntu.edu.tw/rp/95_01/pdf.

Hunt, M. (2011). Learners' perceptions of their experiences of learning subject content through a foreign language. Educational Review, 63(3), 365-378. http://dx.doi.org/10.1080/00131911.2011.571765

Hüttner, Julia, Christiane Dalton-Puffer \& Ute Smit. (2013). The Power of Beliefs: Lay Theories and their Influence on the Implementation of CLIL Programmes. International Journal of Bilingual Education and Bilingualism, 16(3), 267-284. http://dx.doi.org/10.1080/13670050.2013.777385

Ikeda, M. (2013). Does CLIL work for Japanese secondary school students? Potential for the "weak" version of CLIL. International CLIL Research Journal, 2(1), 31-42. Retrieved from http://www.icrj.eu/21/article3.html

Ikeda, M. (2013). Does CLIL work for Japanese secondary school students? Potential for the weak version of CLIL. International CLIL Research Journal, 2(1), 31-43.

Jappinen, A-K. (2005). Thinking and content learning of Mathematics and science as cognitional development in Content and Language Integrated Learning (CLIL): Teaching through a foreign language in Finland. Language and Education, 19(2), 147-168.

Kiely, R. (2009). CLIL-the question of assessment. Developing-teachers.com. http://www.developingteachers.com/articles_tchtraining/chill_richard.htm (accessed 23 July, 2013).

Kraidy, M.M. (2001). From Imperialism to Glocalization: A Theoretical Framework for the Information Age. In B. Ebo (ed.), Cyberimperialism? Global Relations in the New Electronic Frontier (pp. 27-42). Westport, CT: Praeger 
Lankshear, C. \& Knobel, M. (2004). Teacher research: from design to Design to Implementation. New York: Open University Press.

Lasagabaster, D. \& Siern, J. M. (2009). Language attitudes in CLIL and traditional EFL classes. International CLIL Research Journal, 1(2), 4-17.

Lee, B. C. \& Chang, K.C. (2008). An overview of Content Language Integrated Learning in Asian contexts. Studies in English Education, 13(2), 166-184.

Lee, K. Q. (2015). GEPT KIDS Model Test. Taipei, Taiwan: Learning Publishing.

Li, C. \& Ruan, Z. (2015). Changes in beliefs about language learning among Chinese EAP learners in an EMI context in Mainland China: A socio-cultural perspective. System, 55, 43-52. http://dx.doi.org/ 10.1016/j.system.2015.08.010

Llinares, A. (2017). Classroom interaction in CLIL primary school classrooms: Research insights to inform successful pedagogy. English as a Global Education (EaGLE) Journal, 3(1), 39-62. https://doi.org/10.5565/rev/clil.3

Llinares, A. \& Dalton-Puffer, C. (2015). The role of different tasks in CLIL and students' use of evaluative language. System, 54, 69-79. http://dx.doi.org/10.1016/j.system.2015.05.001

Llinares, A. \& Pastrana, A. (2013). CLIL students' communicative functions across activities and educational level. Journal of Pragmatics, 59, 81-92. http://dx.doi.org/10.1016/j.pragma.2013.05.011

Lo, Y.Y. (2014). L2 learning opportunities in different academic subjects in Content-Based Instruction: Evidence in favor of conventional wisdom. Language and Education, 28(1), 141-160. https://doi.org/10.1080/09500782.2013.786086

Lorenzo, F., Casal, S., Moore, P. (2010). The effects of content and language integrated learning in European education: key findings from the Andalusian sections evaluation project. Applied Linguistics, 31, 418-442. http://dx.doi.org/10.1093/applin/amp041

Mackenzie, A. S. (2008). English next in East Asia. In the Proceeding of primary innovations regional seminar, edited by British Council, 13-30. Bangkok: British Council.

Maggie, F. (2012). Evaluation in CLIL. In F. Quartapelle (Eds.) Assessment and evaluation in CLIL (57-74). AECIL-EACEA.

Marquez, M. (2007). Models of CLIL: An evaluation of its status drawing on the German experience. A critical report on the limits of reality and perspectives. RESLA, 20,95111.

Marsh, D. (2000). Using languages to learn and learning to use languages. In Marsh, D., Lange (Eds.) Using languages to learn and learning to use languages: Introduction to Content and Language Integrated Learning for parents and young people. TIE-CLIL: University of Jyvaskyla and Ministero della Pubblica Istruzione: Milan.

Marsh, D. (2002). CLIL/EMILE the European dimension: Action, trends and foresight potential. Brussels: European Commission.

Marsh, D. \& Hood, P. (2008). Content and Language Integrated Learning in Primary East Asia Contexts (CLIL PEAC). In the Proceeding of Primary Innovations Regional Seminar (p. 43-50). Bangkok: British Council.

Masih, J. (1999). Learning through a foreign language: Models, methods, and outcomes, CILT (Centre for Information on Language Teaching and Research), London.

Mehisto, P., Marsh, D. \& Frigols, M. J. (2008). Uncovering CLIL: Content and Language Integrated Learning in Bilingual and Multilingual Education. Oxford: Macmillan.

Mertler, Craig, A. (2001). Designing scoring rubrics for your classroom. Practical assessment, Research \& Education. Retrieved from: http://pareonline.net/getvn.asp?v=7\&n=25 (last access 29/10/2012).

Meyer, O., Coyle, D., Halbach, A., Schuck, K. \& Ting, T. (2015). A Pluriliteracies approach to content and language integrated learning-mapping leaner progressions in knowledge construction and meaning-making. Language, Culture and Curriculum, 28(1), 41-57. https://doi.org/10.1080/07908318.2014.1000924

Mills, G. (1999). Action Research: A guide for the teacher researcher. Prentice.

Nguyen, T. M. H. (2011). Primary English language education policy in Vietnam: Insights from implementation. Current Issues in Language Planning, 12(2), 225-249. Retrieved from 
http://dx.doi.org/10.1080/14664208.2011.597048

Nieto Moreno de Diezmas, E. (2016). The impact of CLIL on the acquisition of the learning to learn competence in secondary school education in the bilingual programmes of Castilla-La Mancha. Porta Linguarum, 25, 21-34.

Nikula, T. (2015). Hands-on tasks in CLIL science classrooms as sites for subject-specific language use and learning. System, 54, 14-27. http://dx.doi.org/10.1016/j.system.2015.04.003

Niteo Moreno de Diexmas, E. (2016). The impact of CLIL on the acquisition of L2 competences and skills in primary education. International Journal of English Studies, 16(2), 81-101. https://doi.org/10.6018/ijes/2016/2/239611

Pascual, I. \& Basse, R. (2017). Assessment for learning in CLIL classroom discourse: The case of metacognitive questions. Applied Linguistics Perspectives on CLIL, 47, 221-235. https://doi.org/10.1075/11lt.47.13pas

Pavon, V. \& Ellison, M. (2013). Examining teacher roles and competence in Content and Language Integrated Learning (CLIL). Linguarum Arena, 4, 65-78.

Perez-Canado, M. L. (2012). CLIL research in Europe: Past, present and future. International Journal of Bilingual Education and Bilingualism, 15(3), 315-341. http://dx.doi.org/10.1080/13670050.2011.630064

Pladevall-Ballester, E. (2017). CLIL in low proficiency primary school settings: The role of L2 use and focus on form. English as a Global Language Education (EaGLE) Journal, 3(1), 15-38.

Prasongporn, P. (2009). CLIL in Thailand: Challenges and Possibilities. Paper presented at the first Access English EBE Symposium, Jakarta, Indonesia.

Quartapelle, F. \& Schameitat, B. (2012). Teaching and learning with CLIL. In F. Quartapelle (Eds.) Assessment and evaluation in CLIL (29-37). AECIL-EACEA.

Rose, H. (2012). Language learning strategy research: Where do we go from here? Studies in Self-Access Learning Journal, 3, 137-148.

Ruiz de Zarobe, Y. (2013). CLIL implementation: From policy-makers to individual initiative. International Journal of Bilingual Education and Bilingualism, 16(3), 231-243. https://doi.org/10.1080/13670050.2013.777383

Sasajima, S. \& Ikeda, C., Hemme, C. \& Reliey, T. (2011). Current practice and future perspective of Content and Language Integrated Learning (CLIL) in Japan. Paper presented at the JACET 50th (2011) Commemorative International Convention, in Tokyo, Japan, August 31-September 2.

Seikkula-Leino, J. (2007). CLIL learning: Achievement levels and affective factors. Language and Education, 21(4), 328-341. http://dx.doi.org/10.2167/le635.0

Serra, C. (2007). Assessing CLIL at primary school: A longitudinal study. International Journal of Bilingual Education and Bilingualism, 10, 582-602. https://doi.org/10.2167/beb461.0

Soussi, K. (2015). CLIL in Moroccan higher education: A survey of students' responses the case of the National Institute of Post and Telecommunications. IOSR Journal of Humanities and Social Sciences, 20(9), 45-51.

Taggart, G., Phifer S., Nixon, J. \& Wood, M. (1998). Rubrics: A Handbook for Construction and Use. Technomic Publishing Co., Lancaster, Basel.

Tan, P. K. W. (2005). The medium-of-instruction debate in Malaysia: English as a Malaysian language? Language problems and language planning, 29(1), 47-66. https://doi.org/10.1075/lplp.29.1.04tan

Tedick, D. \& Wesley, P. (2015). A review of research on content-based foreign/second language education in US

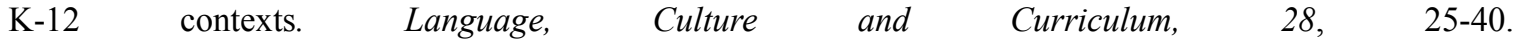
https://doi.org/10.1080/07908318.2014.1000923

Turner, M. (2013). CLIL in Australia: The importance of context. International Journal of Bilingual Education and Bilingualism, 16(4), 395-410. https://doi.org/10.1080/13670050.2012.691086

Woodrow, L. (2005). The challenge of measuring language learning strategies. Foreign Language Annals, 38, 90-95. https://doi.org/10.1111/j.1944-9720.2005.tb02456.x

Wu, W. S. (2006). Students' attitude toward EMI: Using Chung Hua University as an example. Journal of Education and Foreign Language and Literature, 4, 67-84.

Yamano, S. (2013). CLIL in a Japanese primary school: Exploring the potential of CLIL in a Japanese EFL 
context. International CLIL Research Journal, 2(1), 19-30. $\quad$ Retrieved from http://www.icrj.eu/21/article2.html

Yang, W. H. \& Gosling, M. (2014). What makes a Taiwan CLIL program highly recommended or not recommended? International Journal of Bilingual Education and Bilingualism, 17(4), 394-409. https://doi.org/10.1080/13670050.2013.808168

Yang, W. H. (2015). Content and language integrated learning next in Asia: Evidence of learners' achievement in CLIL education from a Taiwan tertiary degree programme. International Journal of Bilingual Education and Bilingualism, 18(4), 361-382. https://doi.org/10.1080/13670050.2014.904840

Yang, W. H. (2017). From similarity to diversity: The changing use of language learning strategies in Content and Language Integrated Learning at the tertiary level in Taiwan. English Teaching \& Learning, 41(1), $1-32$.

Yeh, K. (2008). The effects of incorporating multimedia into Content and Language Integrated Learning method on English reading and learning attitudes of elementary school students. Unpublished Master Thesis. Tamkang University, Taipei, Taiwan.

Zalkapli, A. (2009). Polls show majority support for English policies. The Malaysian Insider (8 July). Available at:

hhtp://www.themalaysiannisider,com/litee./Malaysia/article/Polls-show-majority-support-for-English-polici es/.

\section{Copyrights}

Copyright for this article is retained by the author(s), with first publication rights granted to the journal.

This is an open-access article distributed under the terms and conditions of the Creative Commons Attribution license (http://creativecommons.org/licenses/by/4.0/). 